\title{
PENERAPAN MODEL PEMBELAJARAN MAKE A MATCH UNTUK MENINGKATKAN HASIL BELAJAR SISWA PADA MATERI RUMUS KIMIA DAN TATA NAMA SENYAWA
}

\section{APPLICATION OF MAKE A MATCH LEARNING MODEL TO IMPROVE STUDENT LEARNING OUTCOMES IN MATERIAL CHEMISTRY FORMULATION AND COMPOUND NAME}

\author{
Eva Pratiwi Pane* \& Hisar Marulitua Manurung \\ Universitas HKBP Nommensen Pematangsiantar, Pendidikan Kimia \\ *Corresponding author: evapratiwi2607@gmail.com
}

\begin{abstract}
ABSTRAK
Penelitian ini bertujuan untuk mengetahui hasil belajar siswa yang diajarkan dengan model pembelajaran kooperartif tipe mencari pasangan (make a match) lebih tinggi dari hasil belajar siswa yang diajarkan pembelajaran konvensional pada materi rumus kimia dan tata nama senyawa dan untuk mengetahui berapa besar peningkatan hasil belajar kimia siswa melalui penerapan model pembelajaran kooperatif tipe mencari pasangan (make a match) pada materi rumus kimia dan tata nama senyawa. Penelitian ini menggunakan pendekatan kualitatif. Waktu penelitian dilaksanakan pada bulan November di kelas X semester 1 Tahun Ajaran 2018/2019. Penelitian ini dilaksanakan di SMA Swasta Mars Pematangsiantar. Populasi dalam penelitian ini adalah seluruh siswa kelas X SMA Swasta Mars Pematangsiantar yang berjumlah 6 kelas. Sampel diambil secara acak (random sampling) dengan memilih 2 kelas dari 6 kelas, sehingga diperoleh satu kelas yang diberi pengajaran dengan model pembelajaran kooperatif tipe mencari pasangan (make a match) dan kelas lainnya diberi pengajaran dengan model pembelajaran konvensional. Hasil penelitian yang diperoleh adalah (1) Hasil belajar siswa yang diajarkan dengan model pembelajaran kooperatif tipe mencari pasangan (make a match) lebih tinggi daripada hasil belajar siswa yang menggunakan pembelajaran konvensional di SMA Swasta Mars Pematangsiantar pada materi rumus kimia dan tata nama senyawa, (2) Peningkatan hasil belajar kimia siswa pada pembelajaran kooperatif tipe mencari pasangan (make a match) sebesar 68\% sedangkan peningkatan hasil belajar kimia siswa yang diajar dengan pembelajaran konvensional sebesar $62 \%$. Jadi, terdapat perbedaan peningkatan hasil belajar kimia siswa yang signifikan antara pembelajaran make a match dengan pembelajaran konvensional. Besarnya perbedaan peningkatan hasil belajar kimia siswa adalah 6\%.
\end{abstract}

Kata kunci: make a match, hasil belajar, rumus kimia, tata nama senyawa

\section{ABSTRACT}

This study aims to determine the learning outcomes of students taught with cooperative learning models looking for a partner (make a match) higher than the learning outcomes of students who are taught conventional learning on the material of chemical formulas and compound nomenclature and to find out how much an increase in student chemistry learning outcomes through the application of a type of cooperative learning model looking for a partner (make a match) on the material of chemical formulas 
and nomenclature of compounds. This research uses a qualitative approach. When the research was conducted in November in class X semester 1 of the 2018/2019 Academic Year. This research was conducted at Mars Pematangsiantar Private High School. The population in this study were all class $X$ students of Pematangsiantar Mars Private High School, totaling 6 classes. Samples were taken randomly (random sampling) by selecting 2 classes from 6 classes, so that one class was given teaching with a cooperative learning model type of looking for a partner (make a match) and the other classes were taught with conventional learning models. The research results obtained are (1) Student learning outcomes taught by the type of cooperative learning model looking for a partner (make a match) are higher than the learning outcomes of students who use conventional learning in Mars Pematangsiantar Private High School on the material of chemical formulas and compound nomenclature, (2) Increase in student chemistry learning outcomes in cooperative learning looking for partners (make a match) while $68 \%$ increase in chemistry learning outcomes of students taught with conventional learning by $62 \%$. So, there is a significant difference in the increase in student chemistry learning outcomes between make a match learning and conventional learning. The magnitude of the difference in improvement in student chemistry learning outcomes is $6 \%$.

Keywords: make a match, learning outcomes, chemical formulas, compound nomenclature

\section{PENDAHULUAN}

Pendidikan memegang peranan penting dalam membangun suatu bangsa. Tanpa adanya pendidikan, perkembangan suatu bangsa tidak akan mungkin terjadi. Untuk mengolah akal pikirnya diperlukan suatu pola pendidikan melalui suatu proses pembelajaran.

Pelaksanaan pengajaran di dalam kelas merupakan tugas utama guru dan pembelajaran diartikan sebagai suatu kegiatan yang ditujukan untuk membelajarkan siswa. Permasalahan yang dihadapi dunia pendidikan kita adalah lemahny proses pembelajaran. Mata pelajaran science tidak dapat mengembangkan kemampuan anak berpikir kritis dan sistematis, karena strategi pembelajaran di dalam kelas.

Salah satu masalah yang dihadapi dunia pendidikan kita adalah masalah lemahnya proses pembelajaran. Dalam proses pembelajaran, anak kurang didorong untuk mengembangkan kemampuan berpikir. Proses pembelajaran di dalam kelas diarahkan kepada kemampuan anak untuk menghafal informasi; otak anak dipaksa untuk mengingat dan menimbun berbagai informasi tanpa dituntut untuk memahami informasi yang diingatnya itu untuk menghubungkannya dengan kehidupan sehari-hari. Akibatnya ketika anak didik lulus dari sekolah, mereka pintar secara teoritis, akan tetapi mereka miskin aplikasi.

Menurut Tarmizi (2008) Pembelajaran terpusat pada guru sampai saat ini masih menemukan beberapa kelemahan. Kelemahan tersebut dapat dilihat pada saat berlangsungnya proses pembelajaran di kelas, interaksi siswa dengan guru atau siswa dengan siswa jarang terjadi. Siswa kurang terampil dalam menjawab pertanyaan atau bertanya tentang konsep yang diajarkan. Siswa kurang bisa bekerja dalam kelompok diskusi dan memecahkan masalah yang diberikan. Siswa cenderung belajar sendiri-sendiri.

Pembelajaran yang disampaikan dengan ceramah membuat siswa bosan, tidak bersemangat di kelas, kurang aktif dalam bertanya dan menjawab pertanyaan dan tidak berantusias saat berdiskusi kelompok dengan temannya. Oleh karena itu, peneliti membuat model pembelajaran kooperatif tipe mencari pasangan (make a match) yang membuat siswa dapat bekerja dengan teman-temannya di kelas dan melibatkan seluruh siswa dikelas.

Ilmu kimia merupakan salah satu mata pelajaran IPA yang kurang diminati, bahkan banyak siswa yang menganggap pelajaran kimia menakutkan, karena banyak siswa yang terlebih dahulu merasa kurang mampu dalam mempelajari kimia dan merasa bahwa kimia adalah pelajaran yang sulit dan membosankan. Akibatnya, hasil belajar kimia siswa relatif rendah. Selain faktor individu siswa tersebut, pengajaran kimia yang disajikan juga kurang menarik sehingga mempengaruhi rendahnya motivasi siswa dalam belajar kimia. 
Salah satu kondisi yang dianggap mampu memperbaiki kondisi diatas adalah menjadikan kegiatan diskusi dengan menerapkan model pembelajaran kooperatif tipe mencari pasangan (make a match) yang diperkenalkan oleh Lurna Curran dalam Lie (2002). Make a match adalah kegiatan belajar untuk mencari pasangan kartu yang merupakan jawaban soal sebelum batas waktunya, siswa yang dapat mencocokkan kartunya akan diberi point dan yang tidak berhasil mencocokkan kartunya akan diberi hukuman sesuai dengan yang telah disepakati bersama.

Dengan adanya model pembelajaran kooperatif tipe mencari pasangan (make a match) siswa lebih aktif untuk mengembangkan kemampuan berpikir. Disamping itu make a match juga memberikan kesempatan kepada siswa untuk bertanya dan mngeluarkan pendapat serta berinteraksi dengan siswa yang menjadikan aktif dalam kelas.

Penelitian yang berkaitan dengan dilakukan oleh Utomo (2010). Hasil penelitian menunjukkan bahwa Pengaruh Persepsi Siswa Tentang Metode Make A Match Dan Motivasi Belajar Terhadap Hasil Belajar Ekonomi Pada Siswa Kelas X SMA Negeri 1 Wuryantoro T.A. 2009/2010 dengan persentase perbedaan hasil belajar sebesar 60,3\%. Penelitian lain yang dilakukan Ratna (2009) meneliti Pembelajaran Kimia Model Think Pairs Share (TPS) dan Model Make A Macth dengan rata-rata persentase peningkatan hasil belajar sebesar $75,2 \%$.

Tata nama senyawa merupakan salah satu pokok bahasan mata pelajaran kimia kelas X SMA yang isi materinya bersifat abstrak. Dalam materi tata nama senyawa ini akan dibahas mengenai rumus kimia, rumus molekul, dan tata nama senyawa. Standar kompetensi yang dituntut pada pokok bahasan tata nama senyawa ialah memahami cara menuliskan nama senyawa kimia, rumus kimia dan rumus molekul. Oleh karena itu, alangkah baiknya jika siswa diajak untuk menyenangi materi ini dengan memberikan strategi, pendekatan, model, ataupun metode pembelajaran yang menarik bagi siswa. Dalam penelitian Irmayasopa Ginting (2010), pengaruh pendekatan kontruktivisme dengan model pembelajaran kooperatif tipe think pair share (berbagi-berpikir-berpasangan) terhadap hasil belajar kimia siswa pada pokok bahasan lambang unsur dan rumus kimia menunjukkan peningkatan sebesar $10,08 \%$. Hal yang sama juga terjadi pada penelitian Yayuk Arianti (2011), pengaruh model learning game terhadap motivasi dan hasil belajar siswa dalam pembelajaran kimia di kelas X SMK pada pokok bahasan tata nama senyawa kimia menunjukkan peningkatan sebesar $79,5 \%$.

Tujuan dalam penelitian ini adalah untuk mengetahui hasil belajar siswa yang diajarkan dengan model pembelajaran kooperartif tipe mencari pasangan (make a match) lebih tinggi dari hasil belajar siswa yang diajarkan pembelajaran konvensional pada materi rumus kimia dan tata nama senyawa dan untuk mengetahui berapa besar peningkatan hasil belajar kimia siswa melalui penerapan model pembelajaran kooperatif tipe mencari pasangan (make a match) pada materi rumus kimia dan tata nama senyawa Sedangkan manfaat yang diharapkan dalam penelitian ini adalah meningkatkan pemahaman siswa mengenai materi tata nama senyawa dan meningkatkan hasil belajar kimia siswa, membuka wawasan berpikir guru dalam mengajar dan mengembangkan model pembelajaran dalam proses belajar mengajar dan untuk menjadi bahan masukan bagi guru kimia dalam memilih model pembelajaran yang tepat., meningkatkan kualitas dan mutu sekolah melalui peningkatan hasil belajar siswa dan kinerja guru dan sebagai bahan informasi bagi peneliti lain untuk dapat mengembangkan penelitian selanjutnya tentang model pembelajaran kooperatif tipe mencari pasangan (make a match) dan sebagai referensi bagi peneliti dalam melakukan penelitian yang lebih lanjut.

\section{METODE PENELITIAN/ RESEARCH METHOD}

\subsection{Jenis Penelitian}

Penelitian ini menggunakan pendekatan kualitatif.

\subsection{Waktu dan Tempat Penelitian}


Waktu penelitian dilaksanakan pada bulan November di kelas $\mathrm{X}$ semester 1 Tahun Ajaran 2018/2019. Penelitian ini dilaksanakan di SMA Swasta Mars Pematangsiantar.

\subsection{Target/Subjek Penelitian}

Populasi dalam penelitian ini adalah seluruh siswa kelas X SMA Swasta Mars Pematangsiantar yang berjumlah 6 kelas. Sampel diambil secara acak (random sampling) dengan memilih 2 kelas dari 6 kelas, sehingga diperoleh satu kelas yang diberi pengajaran dengan model pembelajaran kooperatif tipe mencari pasangan (make a match) dan kelas lainnya diberi pengajaran dengan model pembelajaran konvensional.

\subsection{Prosedur}

Prosedur dalam penelitian ini meliputi (1) Tahap Persiapan, yaitu menetapkan jadwal penelitian, menyusun Rencana Pelaksanaan Pengajaran (RPP) sebagai acuan dalam pelaksanaan pengajaran, menyusun soal-soal untuk instrumen penelitian dan model pembelajaran Make a Match, serta menguji soal yang akan digunakan dengan cara validasi kepada siswa dengan menghitung Validasi, Reliabilitas, Tingkat Kesukaran Tes dan Daya Pembeda Tes; (2) Tahap Pelaksanaan yaitu menentukan sampel penelitian (kelas eksperimen dan kelas kontrol) dari dua kelas yang digunakan, melakukan pre test pada sampel penelitian untuk mengetahui hasil belajar siswa sebelum diberi perlakuan yang bertujuan untuk menguji homogenitas dan normalitas dari kedua kelompok sampel dan mengetahui gambaran tentang kemampuan awal siswa sebelum diberikan perlakuan yang berbeda tentang materi yang akan dibahas sekaligus untuk membagi siswa kedalam kelompok belajar tipe mencari pasangan (make a match) pada kelompok eksperimen, serta memberikan perlakuan yang berbeda kepada kedua kelas sampel dan mengadakan post test pada pertemuan terakhir untuk mendapatkan data kemampuan sampel penelitian untuk melihat peningkatan hasil belajar setelah pengajaran selesai dilakukan; (3) Tahap Pengolahan Data yaitu mengolah data untuk melihat bagaimana peningkatan prestasi belajar antara sampel yang diberi pengajaran dengan menerapkan model pembelajaran kooperatif tipe mencari pasangan (make a match) dengan sampel yang diberi pengajaran dengan metode konvensional dan menarik kesimpulan.

\subsection{Data, Instrumen, dan Teknik Pengumpulan Data}

Instrumen dalam penelitian ini berjumlah 20 item soal pilihan berganda dengan lima pilihan (option). Sebelum melakukan penelitian tes yang telah disusun terlebih dahulu diujicobakan untuk mengetahui validitas tes, reliabilitas tes, tingkat kesukaran tes dan daya pembeda tes.

\subsection{Teknik Analisis Data}

Dalam penelitian ini data yang diperoleh adalah dari kelas eksperimen dan kelas kontrol. Penskoran pilihan ganda dapat dilakukan dengan rumus :

$$
\begin{aligned}
\text { skor }=\frac{B}{N} \times 100, \text { dimana } \mathrm{B} & =\text { banyaknya butir soal yang dijawab benar } \\
\mathrm{N} & =\text { banyak butir soal keseluruhan. }
\end{aligned}
$$

Setelah data dari kelas diperoleh, maka langkah-langkah yang dilakukan sebagai berikut :

\section{Menghitung Rata-rata dan Simpangan baku}

a. Rata-rata (Mean) 


$$
\bar{X}=\frac{\sum X_{i}}{N}
$$

Keterangan :

$$
\begin{aligned}
\bar{X} & =\text { Mean (rata-rata) nilai siswa } \\
\sum X_{i} & =\text { Jumlah nilai siswa } \\
& =\text { Jumlah siswa }
\end{aligned}
$$

\section{b. Simpangan Baku (Standar Deviasi)}

$$
S=\sqrt{\frac{N \sum X_{i}^{2}-\left(\sum X_{i}\right)^{2}}{N(N-1)}} \quad \text { (Sudjana, 2005) }
$$

\section{Uji Normalitas Data} langkah :

Uji normalitas yang digunakan dalam penelitian ini adalah uji Chi-kuadrat dengan langkah-

a. Menentukan jumlah kelas interval (untuk uji Chi-kuadrat jumlah kelas interval ditetapkan $=6$ ).

Hal ini sesuai dengan 6 bidang yang ada pada Kurva Normal Baku

b. Menentukan panjang kelas interval (PK) dengan rumus:

$$
\text { Panjang Kelas }=\frac{\text { Data terbesar }- \text { Data terkecil }}{6}
$$

c. Menyusun data kedalam tabel penolong untuk menentukan harga Chi-kuadrat hitung, dimana rumus untuk menghitung Chi-kuadrat hitung yaitu:

$$
X_{\text {hitung }}^{2}=\frac{(f o-f h)^{2}}{f h}
$$

d. Membandingkan harga Chi-kuadrat hitung $\left(\mathrm{X}^{2}\right)$ dengan harga Chi-kuadrat tabel pada $\alpha=0,05$ dengan $\mathrm{db}=5$. Jika Chi-kuadrat hitung $\left(\mathrm{X}^{2}\right)<$ harga Chi-kuadrat tabel maka data tersebut berdistribusi normal (Silitonga,2011).

\section{Uji Homogenitas}

Untuk uji homogenitas digunakan rumus (Sudjana, 2005)

$\mathrm{H}_{\mathrm{o}}: \sigma_{1}^{2}=\sigma_{2}^{2}$ atau kedua populasi mempunyai varians yang sama $\mathrm{H}_{\mathrm{o}}: \sigma_{1}^{2} \neq \sigma_{2}^{2}$ atau kedua populasi tidak mempunyai varians yang sama

Kesamaan varians ini akan diuji dengan rumus:

$$
F=\frac{\text { varians terbesar }}{\text { varians terkecil }}
$$

Kriteria pengujian:

Jika $\mathrm{F}_{\text {hitung }}<\mathrm{F}_{\text {tabel }} \mathrm{H}_{0}$ diterima (mempunyai varians yang sama) dan jika $\mathrm{F}$ hitung $\geq \mathrm{F}$ tabel $\mathrm{H}_{0}$ ditolak (mempunyai varians yang berbeda). Dimana $\mathrm{F}$ tabel $=\mathrm{F}_{1 / 2}\left(\mathrm{~V}_{1}, \mathrm{~V}_{2}\right)$ dengan peluang $\alpha=0,05$ dengan derajat kebebasan $\mathrm{V}_{1}=\mathrm{n}_{1}-1$ dan $\mathrm{V}_{2}=\mathrm{n}_{2}-1$

Dimana: $\mathrm{n}_{1}=$ ukuran sampel yang bervarians terbesar

\section{Uji Hipotesis}

$$
\mathrm{n}_{2}=\text { ukuran sampel yang bervarians terkecil }
$$

Hipotesis yang akan diuji adalah :

$\mathrm{H}_{0}: \mu_{1} \leq \mu_{2}$

$\mathrm{H}_{\mathrm{a}}: \mu_{1}>\mu_{2}$

Maka untuk mengetahui adanya perbedaan rata-rata digunakan uji-t yakni uji t pihak kanan . Rumus uji-t yang digunakan adalah: 


$$
t_{\text {hitung }}=\frac{\overline{X_{1}}-\overline{X_{2}}}{\sqrt{\frac{S_{1}^{2}}{n_{1}}+\frac{S_{2}{ }^{2}}{n_{2}}}}
$$

(Silitonga, 2011)

Dimana:

$$
\mathrm{S}^{2}=\frac{\left(n_{1}-1\right) S_{1}^{2}+\left(n_{2}-1\right) S_{2}^{2}}{n_{1}+n_{2}-2} \quad \text { (Silitonga, 2011) }
$$

Keterangan :

$\mathrm{t}:$ Harga $\mathrm{t}$ hasil perhitungan

$\mathrm{X}_{1}, \mathrm{X}_{2} \quad$ : Rata-rata skor kelas eksperimen dan kelas kontrol

$\mathrm{n}_{1,} \mathrm{n}_{2} \quad$ : Jumlah sampel kelas eksperimen dan kelas kontrol

$\mathrm{S}_{1}{ }^{2}, \mathrm{~S}_{2}{ }^{2}$ : Varians kelas eksperimen dan kelas kontrol

Jika $t_{\text {hitung }}>t_{\text {tabel }}$ pada taraf nyata 0,05 dan derajat kebebasan $(d k)=n_{1}+n_{2}-2$ Berarti hipotesis $H_{a}$ diterima. Dan jika $t_{\text {hitung }}<\mathrm{t}_{\text {tabel }}$ pada taraf nyata 0,05 dan derajat kebebasan $(\mathrm{dk})=\mathrm{n}_{1}+\mathrm{n}_{2}-2$ berarti hipotesis $\mathrm{H}_{0}$ diterima.

\section{Uji Gain (Peningkatan Hasil Belajar)}

Menurut Meltzer (dalam Dwiyanti, 2010) persen peningkatan hasil belajar dapat dihitung dengan rumus g faktor (gain score ternormalisasi). Rumus g faktor digunakan untuk mengetahui perolehan hasil belajar siswa. Persentase peningkatan hasil belajar dapat langsung dicari rata-rata nilai gain seluruh siswa untuk masing-masing kelas.

Rumus g faktor yang digunakan adalah sebagai berikut :

$$
g=\frac{\text { nilai post test }- \text { nilai pretest }}{\text { nilaimaksimum-nilai pretest }}
$$

Range nilai:

$\mathrm{g}<0,3 \quad$ : hasil belajar rendah

$0,3 \leq \mathrm{g} \leq 0,7 \quad:$ hasil belajar sedang

$\mathrm{g}>0,7 \quad$ : hasil belajar tinggi

\section{HASIL DAN PEMBAHASAN}

\subsection{Analisis Data dan Instumen Penelitian}

Sebelum melaksanakan penelitian, terlebih dahulu dilaksanakan uji coba instrumen tes penelitian yang bertujuan untuk mengetahui tingkat validitas, reliabilitas, tingkat kesukaran dan daya pembeda dari instrumen tes. Uji coba ini dilaksanakan pada siswa kelas X SMA Swasta Mars Pematangsiantar.

Dari uji coba tes tersebut diketahui bahwa:

1. Validitas Tes

Dari 30 soal yang diujikan terdapat 20 soal yang valid dan dianggap layak untuk diujikan dan 10 soal yang tidak valid dan dianggap tidak layak untuk dipergunakan sebagai instrumen tes penelitian. Dalam penelitian ini, instrumen yang digunakan untuk pengumpulan data adalah 20 soal yang valid tersebut. Perhitungan validitas tes dilakukan dengan menggunakan korelasi product moment.

2. Reliabilitas Tes

Berdasarkan perhitungan dengan menggunakan uji Kuder dan Ricardson 20 (KR-20), diperoleh $r_{\text {hitung }}=0,8$ di mana $r_{\text {tabel }}=0,361$. Karena $r_{\text {hitung }}>r_{\text {tabel }}$, maka test secara keseluruhan dinyatakan reliabel. Dimana $r_{\text {hitung }}$ diperoleh dari tabel harga kritik dan $r$ product moment. 


\section{Tingkat Kesukaran Tes}

Dari 30 soal yang diujikan terdapat 26 soal sedang dan 4 soal yang sukar.

4. Daya Pembeda Tes

Dari 30 soal yang diujikan terdapat 9 soal yang daya bedanya baik, 12 soal yang daya bedanya cukup, dan 9 soal yang daya bedanya buruk.

Data hasil penelitian diperoleh sebelum kedua sampel diberikan perlakuan yang berbeda terlebih dahulu diberikan tes awal yang bertujuan untuk mengetahui kemampuan awal masing-masing siswa pada kedua kelas, serta untuk mengetahui kedua kelas tersebut terdistribusi normal dan homogen. Selanjutnya dilakukan pembelajaran yang berbeda yaitu kelas eksperimen dengan model pembelajaran kooperatif tipe mencari pasangan (Make A Match) dan kelas kontrol dengan model pembelajaran konvensional. Pada akhir proses pembelajaran akan diberikan tes akhir untuk mengetahui hasil belajar siswa. Berdasarkan hasil penelitian setelah dilakukan perhitungan diperoleh rata- rata pre test untuk kelas eksperimen $(27,81)$ dan untuk kelas kontrol $(22,03)$. Sedangkan nilai untuk post-test pada kelas eksperimen $(76,88)$ dan untuk kelas kontrol $(70,47)$.. Dari hasil perhitungan peningkatan hasil belajar kelas eksperimen sebesar $68 \%$ sedangkan peningkatan hasil belajar kelas kontrol sebesar $62 \%$.

\subsection{Analisisa Data Hasil Belajar}

Sebelum kedua sampel diberikan perlakuan yang berbeda terlebih dahulu diberikan tes awal yang bertujuan untuk mengetahui kemampuan awal masing-masing siswa pada kedua kelas,serta untuk mengetahui kedua kelas tersebut terdistribusi normal dan homogen. Selanjutnya dilakukan pembelajaran yang berbeda yaitu kelas eksperimen dengan model pembelajaran kooperatif tipe mencari pasangan (Make A Match) dan kelas kontrol dengan model pembelajaran konvensional. Pada akhir proses pembelajaran akan diberikan tes akhir untuk mengetahui hasil belajar siswa. Berdasarkan hasil penelitian setelah dilakukan perhitungan diperoleh rata- rata pre test untuk kelas kontrol $(22,03 \pm 6,70)$ dan kelas eksperimen $(27,81 \pm 7,21)$ Sedangkan nilai untuk post-test pada kelas kontrol $(70,47 \pm 6,00)$ dan untuk kelas eksperimen $(76,88 \pm 6,40)$.

Dari perhitungan berdasarkan data tabulasi hasil tes untuk kedua sampel diperoleh nilai pretes dan postes kelas kontrol dan kelas eksperimen dirangkum dalam tabel1:

Tabel 1. Hasil Perolehan Rata-Rata, Standar Deviasi Pre-test dan Post-test

\begin{tabular}{cccccc}
\hline \multirow{2}{*}{ Kelas } & \multicolumn{5}{c}{ Jenis Data } \\
\cline { 2 - 5 } & $\overline{\mathbf{X}}$ & PD & $\overline{\mathbf{X}}$ & SD & \multirow{2}{*}{$\Delta \overline{\mathbf{X}}$} \\
\cline { 2 - 5 } & 22,03 & 6,70 & 70,47 & 6,00 & 48,44 \\
\hline Kontrol & 27,81 & 7,21 & 76,88 & 5,70 & 49,07 \\
\hline Eksperimen & &
\end{tabular}

$\overline{\mathrm{X}}=$ Nilai rata-rata $; \mathrm{SD}=$ Standar Deviasi $\Delta \overline{\mathrm{X}}=$ Selisih Pre-Tes dengan Post-Tes

Pada Tabel 1 menunjukkan bahwa kelas Eksperimen memiliki peningkatan lebih tinggi sebesar 49,07 dibandingkan dengan kelas Kontrol sebesar 48,44 terhadap selisih Pre-Tes dan Post-Tes hasil belajar kimia siswa.

Untuk mengetahui peningkatan hasil belajar siswa maka dari data pre-test dan post-test yang diperoleh kemudian dihitung untuk mendapatkan data gain. Berdasarkan hasil penelitian setelah dilakukan perhitungan dari data gain diperoleh rata-rata kelas kontrol $(0,62 \pm 0,088)$ dan untuk kelas eksperimen $(0,68 \pm 0,085)$.

Dari perhitungan berdasarkan data tabulasi hasil tes untuk kedua sampel diperoleh nilai pre test dan post tes kelas kontrol dan kelas eksperimen dirangkum dalam tabel 2. 
Tabel 2 Rata - Rata dan Standar Deviasi, Varians dari Data Gain

\begin{tabular}{ccccccc}
\hline \multicolumn{3}{c}{ Kelas Eksperimen } & \multicolumn{3}{c}{ Kelas Kontrol } & \multirow{2}{*}{$\Delta \overline{\mathbf{X}}$} \\
\cline { 1 - 5 } $\bar{X}$ & SD & V & $\bar{X}$ & SD & V & \\
\hline 0,68 & 0,085 & 0,0072 & 0,62 & 0,088 & 0,0078 & 0,06 \\
\hline
\end{tabular}

$\overline{\mathrm{X}}=$ Nilai rata-rata; $\mathrm{SD}=$ Standar Deviasi $\Delta \overline{\mathrm{X}}=$ Selisih Pre-Tes dengan Post-Tes

Berdasarkan data pada tabel diatas dapat dilihat peningkatan hasil belajar atau gain kelas eksperimen sebesar 0,68 dengan standar deviasi sebesar 0,085, varians sebesar 0,0072 dan peningkatan kelas kontrol sebesar 0,62 dengan tandar deviasi sebesar 0,088 dan varians sebesar 0,0078. Selisih ratarata peningkatan hasil belajar siswa sebesar 0,06.

\subsubsection{Uji Normalitas Data}

Untuk mengetahui apakah data pre-tes dan post-tes kelas Eksperimen dan kelas kontrol terdistribusi normal atau tidak, maka dilakukan uji Chi-Kuadrat pada taraf nyata $\alpha=0,05$. Berdasarkan hasil uji normalitas pada data pre-tes dan post-ter pada kedua kelas diperoleh data sebagai berikut :

Tabel 3. Uji Normalitas Data Pre-Tes dan Post-Tes

\begin{tabular}{cccccc}
\hline Kelas & Sumber Data & $\mathbf{X}^{\mathbf{2}}{ }_{\text {Hitung }}$ & $\mathbf{X}^{\mathbf{2}}{ }_{\text {Tabel }}$ & $\boldsymbol{\alpha}$ & Keterangan \\
\hline \multirow{2}{*}{ Eksperimen } & Pre-Tes & 5,61 & 11,07 & 00,05 & Distribusi Normal \\
\cline { 2 - 6 } & Post-Tes & 8,7 & 11,07 & 00,05 & Distribusi Normal \\
\hline \multirow{2}{*}{ Kontrol } & Pre-Tes & 3,91 & 11,07 & 00,05 & Distribusi Normal \\
\cline { 2 - 6 } & Post-Tes & 7,7 & 11,07 & 00,05 & Distribusi Normal \\
\hline
\end{tabular}

$\mathbf{X}^{2}=$ chi-Kuadrat; $\alpha=$ taraf signifikansi

Berdasakan tabel 3 disimpulkan bahwa:

a. Uji normalitas data hasil belajar siswa kelas eksperimen diperoleh $\mathrm{X}^{2}{ }_{\text {hitung }}$ untuk pre-test 5,61 dan $\mathrm{X}^{2}$ hitung untuk post-test 8,7 . Dengan mengambil taraf nyata $\alpha=0,05 \mathrm{dan} \mathrm{dk}=5$ adalah 11,07 , dari data terlihat harga Chi Kuadrat $\left(\mathrm{X}^{2}\right.$ hitung $)<$ harga Chi Kuadrat $\left(\mathrm{X}^{2}\right.$ tabel $)$ maka dapat disimpulkan data hasil belajar kimia siswa berdistribusi normal.

b. Uji normalitas data nilai hasil belajar siswa kelas kontrol diperoleh $\mathrm{X}^{2}$ hitung untuk pre-test 3,91 dan $\mathrm{X}^{2}$ hitung untuk post-test 7,7. Dengan mengambil taraf nyata $\alpha=0,05 \mathrm{dan} \mathrm{dk}=5$ adalah 11,07 , dari data terlihat harga Chi Kuadrat $\left(\mathrm{X}^{2}\right.$ hitung $)<$ harga Chi Kuadrat $\left(\mathrm{X}_{\text {tabel }}{ }\right)$ maka dapat disimpulkan data hasil belajar kimia siswa berdistribusi normal.

Tabel 4. Uji Normalitas Data Gain

\begin{tabular}{|c|c|c|c|c|c|}
\hline Kelas & Sumber Data & $\mathbf{X}^{2}$ Hitung & $\mathbf{X}^{2}$ Tabel & $\alpha$ & Keterangan \\
\hline Eksperimen & \multirow{2}{*}{ Gain } & 9,58 & 11,07 & 0,05 & Distribusi Normal \\
\hline Kontrol & & 9,26 & 11,07 & 0,05 & Distribusi Normal \\
\hline
\end{tabular}

Berdasakan tabel 4. disimpulkan bahwa:

a. Uji normalitas data hasil belajar siswa kelas eksperimen diperoleh $\mathrm{X}^{2}$ hitung untuk Gain 9,58. Dengan mengambil taraf nyata $\alpha=0,05 \mathrm{dan} \mathrm{dk}=5$ adalah 11,07 , dari data terlihat harga Chi Kuadrat $\left(\mathrm{X}^{2}\right.$ hitung $)$ $<$ harga Chi Kuadrat $\left(\mathrm{X}_{\text {tabel }}^{2}\right)$ maka dapat disimpulkan data hasil belajar kimia siswa berdistribusi normal.

b. Uji normalitas data nilai hasil belajar siswa kelas kontrol diperoleh $\mathrm{X}^{2}{ }_{\text {hitung }}$ untuk Gain 9,26. Dengan mengambil taraf nyata $\alpha=0,05 \mathrm{dan} \mathrm{dk}=5$ adalah 11,07 , dari data terlihat harga Chi Kuadrat $\left(\mathrm{X}^{2}\right.$ hitung $)$ $<$ harga Chi Kuadrat $\left(\mathrm{X}_{\text {tabel }}^{2}\right)$ maka dapat disimpulkan data hasil belajar kimia siswa berdistribusi normal 


\subsubsection{Uji Homogenitas Data}

Uji homogenitas bertujuan untuk melihat apakah kedua data yang berasal dari sampel yang berbeda adalah homogen. Berdasarkan Perhitungan uji homogenitas dari data pretes dan postes dari kedua sampel diperoleh data sebagai berikut

Tabel 5 Uji Homogenitas Kelas Eksperimen dan Kelas Kontrol

\begin{tabular}{|c|c|c|c|c|c|}
\hline $\begin{array}{c}\text { Sumber } \\
\text { Data }\end{array}$ & Kelas & $\mathbf{S}^{2}$ & $\mathbf{F}_{\text {hitung }}$ & $\mathbf{F}_{\text {tabel }}$ & Keterangan \\
\hline \multirow{2}{*}{ Pre-Tes } & Kontrol & 45,00 & \multirow{2}{*}{1,16} & \multirow{2}{*}{1,8245} & \multirow{2}{*}{ Data Homogen } \\
\hline & Eksperimen & 52,00 & & & \\
\hline \multirow{2}{*}{ Post-Tes } & Kontrol & 36,00 & \multirow{2}{*}{1,125} & \multirow{2}{*}{1,8245} & \multirow{2}{*}{ Data Homogen } \\
\hline & Eksperimen & 32,00 & & & \\
\hline
\end{tabular}

$\mathrm{S}^{2}=$ Varians Sampel; $\mathrm{F}_{\text {Tabel }}=\mathrm{dk}(\mathrm{n}-1),(\mathrm{n}-1)(\alpha=0,05)$

Dari data tabel 5 diperoleh harga $F_{\text {hitung }}$ Pre-tes $=1,16$ sedangkan harga $F_{\text {hitung }}$ Post-tes $=1,125$. Berdasarkan tabel nilai untuk distribusi $F$ dengan taraf nyata $\alpha=0,05$ dan dk pembilang 31 serta dk penyebut $31\left(\mathrm{~F}_{\mathrm{o}}(31,31)\right.$ diperoleh harga $\mathrm{F}_{\text {tabel }}=1,8245$ (dengan interpolasi). Karena harga $\mathrm{F}_{\text {hitung }}<\mathrm{F}_{\text {tabel}}$, maka simpulkan bahwa Pre-tes dan post-test dari kedua kelas tersebut adalah homogen. sebagai berikut :

Berdasarkan perhitungan uji homogenitas dari data gain dari kedua sampel diperoleh data Tabel 6 Uji Homogenitas Data Gain

\begin{tabular}{lccccc}
\hline $\begin{array}{c}\text { Sumber } \\
\text { Data }\end{array}$ & Kelas & $\mathbf{S}^{2}$ & $\mathbf{F}_{\text {hitung }}$ & $\mathbf{F}_{\text {tabel }}$ & \multirow{2}{*}{ Keterangan } \\
\cline { 1 - 2 } Gain & Eksperimen & 0,0072 & \multirow{2}{*}{1,08} & \multirow{2}{*}{1,8245} & \multirow{2}{*}{ Data Homogen } \\
\cline { 2 - 3 } & Kontrol & 0,0078 & &
\end{tabular}

Dari data tabel 6 diperoleh harga $F_{\text {hitung }}$ Gain $=1,08$. Berdasarkan tabel nilai untuk distribusi $F$ dengan taraf nyata $\alpha=0,05$ dan dk pembilang 31 serta dk penyebut $31\left(F_{o}(31,31)\right.$ diperoleh harga $F_{\text {tabel }}$ $=1,8245$ (dengan interpolasi). Karena harga $F_{\text {hitung }}<\mathrm{F}_{\text {tabel, }}$ maka simpulkan bahwa Pre-tes dan post-test dari kedua kelas tersebut adalah homogen.

\subsubsection{Uji Hipotesis Penelitian}

Ho : Hasil belajar kimia siswa setelah diberikan pelakuan model pembelajaran kooperatif tipe mencari pasangan (make a match) tidak lebih tinggi dibandingkan dengan pembelajaran konvensional pada pokok bahasan rumus kimia dan tata nama senyawa kelas X SMA. $\left(\mu_{1} \leq \mu_{2}\right)$

$\mathrm{Ha}$ : Hasil belajar kimia siswa setelah diberikan perlakuan model pembelajaran kooperatif tipe mencari pasangan (make a match) lebih tinggi dibandingkan dengan pembelajaran konvensional pada pokok bahasan rumus kimia dan tata nama senyawa. $\left(\mu_{1}>\mu_{2}\right)$

Setelah diketahui bahwa data terdistribusi normal dan homogen maka dapat dilakukan uji hipotesis dengan menggunakan uji statistik uji t satu pihak, yaitu pihak kanan. Uji ini untuk mengetahui apakah hipotesis dalam penelitian ini diterima atau ditolak. Kriteria pengujian jika $t_{\text {hitung }}>t_{\text {tabel }}$ maka hipotesis alternatif diterima dan hipotesis nihil ditolak (lampiran 26). Data hasil uji hipotesis seperti pada tabel 7 dibawah ini : 
Tabel 7. Hasil Uji Hipotesis Data Post Test

\begin{tabular}{|c|c|c|c|c|}
\hline \multicolumn{2}{|r|}{ Data Kelas } & $t_{\text {hitung }}$ & $t_{\text {tabel }}$ & Keterangan \\
\hline Eksperimen & Kontrol & & & \\
\hline $\begin{array}{l}\bar{X}=76,88 \\
\mathrm{SD}=5,70 \\
\mathrm{~S}^{2}=32,00\end{array}$ & $\begin{array}{l}\bar{X}=70,47 \\
\mathrm{SD}=6,00 \\
\mathrm{~S}^{2}=36,00\end{array}$ & 3,05 & 1,6705 & $\begin{array}{l}\text { Ha diterima, Ho } \\
\text { ditolak }\end{array}$ \\
\hline
\end{tabular}

Dari data distribusi t diperoleh $\mathrm{t}_{\text {tabel }}=1,6705$. sedangkan berdasarkan perhitungan diperoleh $\mathrm{t}_{\text {hitung }}$ $=3,05$ sehingga harga $t_{\text {hitung }}>t_{\text {tabel }}(3,05>1,6705)$. Dengan demikian kriteria pengujian hipotesis $t_{\text {hitung }}>$ $\mathrm{t}_{\text {tabel }}$ terpenuhi. Artinya $\mathrm{H}_{0}$ ditolak, Ha diterima yang berarti dapat disimpulkan bahwa hasil belajar kimia siswa yang diajarkan dengan model pembelajaran kooperartif tipe mencari pasangan (make a match) pada materi rumus kimia dan tata nama senyawa.

\subsubsection{Peningkatan Hasil Belajar}

Berdasarkan perhitungan gain ternormalisasi pada kedua kelas, disimpulkan bahwa pada kelas eksperimen terdapat kategori gain tinggi sebanyak 23 siswa, gain sedang sebanyak 9 siswa, sedangkan gain rendah tidak ada. Sedangkan pada kelas kontrol terdapat kategori gain tinggi sebanyak 5 siswa, gain sedang sebanyak 27 siswa, gain rendah juga tidak ada. Data ini diperoleh dari lampiran 27 dan 29. Dimana untuk menentukan kriteria gain adalah $\mathrm{g}>0,7$ tinggi; $0,3<\mathrm{g}<0,7$ sedang; $\mathrm{g}<0,3$ rendah.

Berdasarkan perhitungan gain ternormalisasi pada kedua kelas, yang diperoleh dari lampiran 28 dan 30, maka dapat disajikan data gain pada tabel 8.

\section{Tabel 8. Data Rata-Rata Gain Kelas Eksperimen dan Kelas Kontrol}

\begin{tabular}{|c|c|}
\hline Kelas & Data \\
\hline Eksperimen & $\begin{array}{l}\sum X=21,78 \\
\frac{X}{X} \quad=0,68 \text { (kriteria gain sedang) } \\
S^{2}=0,085 \\
S \quad=0,0072\end{array}$ \\
\hline Kontrol & $\begin{array}{l}\sum X=19,78 \\
\frac{X}{X} \quad=0,62 \text { (kriteria gain sedang) } \\
S^{2} \quad=0,088 \\
S \quad=0,0078\end{array}$ \\
\hline
\end{tabular}

Untuk melihat peningkatan hasil belajar kimia siswa kelas eksperimen dan kelas kontrol dilihat dari rata-rata gain ternormalisasi kelas eksperimen dan kelas kontrol dikali 100\%. Data peningkatan hasil belajar siswa kelas eksperimen dan kelas kontrol disajikan pada tabel 9 di bawah ini :

Tabel 9. Peningkatan Hasil Belajar Kimia Siswa Kelas Eksperimen Dan Kelas Kontrol

\begin{tabular}{cc}
\hline Kelas Eksperimen & Kelas Kontrol \\
\hline 0,68 & 0,62 \\
\hline $68 \%$ & $62 \%$ \\
\hline
\end{tabular}

Berdasarkan tabel diatas dapat dilihat bahwa peningkatan hasil belajar kimia siswa kelas eksperimen lebih tinggi dari pada hasil belajar kimia siswa kelas kontrol. 


\section{SIMPULAN DAN SARAN}

\section{1 Simpulan}

Berdasarkan hasil penelitian yang telah dilakukan maka dapat diambil kesimpulan yaitu : (1) Hasil belajar siswa yang diajarkan dengan model pembelajaran kooperatif tipe mencari pasangan (make a match) lebih tinggi daripada hasil belajar siswa yang menggunakan pembelajaran konvensional di SMA Swasta Mars Pematangsiantar pada materi rumus kimia dan tata nama senyawa, (2) Peningkatan hasil belajar kimia siswa pada pembelajaran kooperatif tipe mencari pasangan (make a match) sebesar 68\% sedangkan peningkatan hasil belajar kimia siswa yang diajar dengan pembelajaran konvensional sebesar $62 \%$. Jadi, terdapat perbedaan peningkatan hasil belajar kimia siswa yang signifikan antara pembelajaran make a match dengan pembelajaran konvensional. Besarnya perbedaan peningkatan hasil belajar kimia siswa adalah $6 \%$.

\section{2 Saran}

Berdasarkan pembahasan dan kesimpulan yang telah dikemukakan di atas maka penulis menyarankan (1) Bagi guru dan calon guru diharapkan dapat menerapkan pembelajaran kooperatif tipe mencari pasangan (make a match) dapat mempermudah pencapaian tujuan instruksional dan dapat meningkatkan hasil belajar siswa, khususnya mata pelajaran kimia (2) Bagi calon guru sebelum proses mengajar dilakukan, harus mengetahui penguasaan siswa terhadap materi-materi prasyarat dari suatu topik yang akan diajarkan, karena pengetahuan siswa sebelumnya sangat menentukan keberhasilan siswa memahami materi baru yang akan diajarkan.

\section{DAFTAR PUSTAKA}

Arianti, Y., (2011), Pengaruh Model Learning Game Terhadap Motivasi Dan Hasil Belajar Siswa Dalam Pembelajaran Kimia di Kelas X SMK Pada Pokok Bahasan Tata Nama Senyawa Kimia, Skripsi, FMIPA, UNIMED, Medan.

Ginting, I., (2010), Pengaruh Pendekatan Kontruktivisme Dengan Model Pembelajaran Kooperatif Tipe Think Pair Share (Berbagi-Berpikir-Berpasangan) Terhadap Hasil Belajar Kimia Siswa Pada Pokok Bahasan Lambang Unsur Dan Rumus Kimia, Skripsi, FMIPS, UNIMED, Medan.

Lie, A., (2002). Cooperative Learning, Mempraktekkan Cooperative Learning di Ruang-ruang Kelas. Grasindo, Jakarta.

Ratna, S., (2009), Upaya Meningkatkan Minat Belajar Matematika Siswa Kelas VIII SMP Negeri 1 Jetis Bantul Dengan Model Cooveratif Learning Tipe Make A Match, Skripsi, FKIP, UNY, Yogyakarta

Silitonga,P.M., (2011), Statistika: Teori dan Aplikasi dalam Penelitian, Graha Ilmu, Yogyakarta

Sudjana, (2005), Metode Statistika, Tarsito, Bandung.

Suyanti, R. D., (2010), Strategi Pembelajaran Kimia, Penerbit Graha Ilmu, Jakarta

Tarmizi, (2008), http://tarmizi.wordpress.com/2008/12/03/make-a-match/(accessed Februari-April 2011)

Utomo, T.S., (2010), Pengaruh Persepsi Siswa Tentang Metode Make A Match Dan Motivasi Belajar Terhadap Hasil Belajar Ekonomi Pada Siswa Kelas X SMA Negeri 1 Wuryantoro T.A. 2009/2010, Skripsi, FMIPA, UMS, Semarang. 